Strategii interactive de predare a textului liric

Interactive strategies for lyric text teaching

Oxana Gherman, doctor în filologie, lector, Catedra de limba și literatura română, Facultatea de Filologie și Istorie, UPS Ion Creangă, Chișinău

\section{CZU: 821.135.1.09:37.02}

\section{Rezumat}

Prezentul articol conține o serie de recomandări metodice pentru predarea textelor lirice la lecțiile de limbă și literatură română. Sunt prezentate în mod sistematizat strategii didactice și puncte de reper pentru organizarea lecțiilor, având în vedere desfășurarea procesului de receptare a textului liric în câteva etape fundamentale: activități de prelectură (care asigură pregătirea afectivă şi intelectuală a elevilor pentru procesul de decodificare a textului), diverse modalităţi de lectură a poeziei și activităţi postlectorale (analiză, interpretare, evaluare și integrare). Pentru fiecare etapă a demersului didactic sunt propuse metode interactive de lucru cu textul liric, care facilitează receptarea eficientă a poeziei de către elevi și stimulează implicarea lor cognitivă, afectivă și creativă în procesul de lucru.

Cuvinte-cheie: text liric, strategii didactice, interacțiune, afectiv, intelectual, creativ, receptare, analiză, interpretare.

\section{Summary}

This article contains a series of methodological recommendations for teaching lyrical texts at Romanian language and literature lessons. There are presented in a systematic way different didactic strategies and landmarks for organizing lessons, taking into account the process of learning/ understanding the lyric text in several fundamental stages: pre-reading activities (which ensure the emotional and intellectual preparation of the students for the process of decoding the studying text), various methods of reading poetry at the lesson and postreading activities (analysis, interpretation, evaluation and integration). For each stage of the didactic approach are proposed some interactive methods of working with the lyric text which facilitate the reception of the poetry by the students and stimulate their cognitive, affective and creative involvement in the working process.

Keywords: lyric text, didactic strategies, interaction, affective, intellectual, creative, reception, analysis, interpretation.

Cursul integrat de limbă şi literatură română presupune învăţ̧area sincronică și 
complementară a faptelor de limbă şi a fenomenelor literare, urmărindu-se formarea profilului etic/ moral/spiritual/social al unui vorbitor cult, dar și a unui cititor avizat, prin „stăpânirea resurselor limbii, a culturii literar-artistice, prin cunoașterea/interpretarea valorilor literare" [6, p. 23]. Caracterul instructiv al literaturii artistice este indiscutabil. Textele literare conţin un fond solid de valori culturale și reprezintă un model rafinat de comunicare scrisă, însă pentru a le transforma în unelte eficiente de cultivare a tinerei generații, este necesar a fi selectate și introduse în procesul instructiv-educativ printr-o strategie didactică bine gândită, adaptată în funcție de un șir de factori: particularitățile individuale ale elevilor, nivelul și potențialul lor intelectual/cognitiv, necesitățile lor spirituale, sociale, profesionale etc.

Procesul de receptare a textului liric în cadrul lecțiilor de limbă și literatură română se desfăşoară în câteva etape: 1) etapa de prelectură (activităţi de reactualizare a cunoștințelor, de anticipare a temei/ideilor/atmosferei lirice, de pregătire psihoafectivă a formanților pentru o receptare optimă, de captare a atenției și provocare a interesului faţă de aspectele ce urmează a fi abordate); 2) etapa de lectură (lectură inițială/tehnică și lecturi repetate, diverse strategii de lectură colectivă şi individuală); 3) etapa de postlectură (activități prin care se expun primele reacții mentale/afective ale elevilor față de textul receptat, înţelegerea stratului de suprafață al textului (prin analiză fonetică, lexicală, morfologică, sintactică, ortografică, punctuațională) și cea de interpretare a stratului de profunzime prin analiză literară, activități de interpretare; activități de evaluare/lectură critică. Parcurgerea în ordine logică a acestor etape, fără a le omite sau exclude pe unele şi suprasolicita pe altele, punând accent pe elementele reprezentative și particulare speciei/stilului/limbajului artistic, va asigura un demers didactic de calitate, prin care receptarea textului liric va avea un impact formativ durabil asupra elevilor, favorizând atingerea finalității educaţiei literar-artistice - „formarea cititorului cult de literatură artistică şi a premiselor pentru educaţia artistic-estetică generală" [5, p. 3].

Având în vedere etapele și fazele prelecturii, lecturii și postlecturii, întregului proces de receptare a unei poezii nu îi este suficientă o singură oră academică. Etapele se vor repartiza în secvenţe didactice separate. Lecția de lectură a unei poezii va începe cu activităţi de prelectură şi se poate încheia cu lectura individuală, exersarea unei lecturi expresive, înregistrarea primelor reacţii, memorizarea fragmentară/integrală a textului. Analizei, interpretării și evaluării textului li se vor dedica timp în funcție de 
numărul de ore programat curricular, respectând consecutivitatea etapelor procesului de receptare.

\section{Activităţi didactice pentru etapa de}

prelectură. Prima parte componentă a secvenței didactice, numită, conform modelului ERR, evocare, va include, în cazul predării unui text literar, activități care precedă lectura. Funcția lor de bază este de a pregăti ,intrarea” cititorului în lumea textului artistic. În special în predarea textului liric, activităţile de prelectură au o pondere foarte mare. Or, delimitarea specificității estetice și decodificarea semnificațiilor hermeneutice ale poeziei lirice succed impactului emoțional pe care îl provoacă lectura ei. Pe de o parte, la etapa de prelectură se realizează trecerea insesizabilă din planul real în cel ficţional, al textului, iar pe de altă parte, se asigură implicarea afectivă şi intelectuală a elevilor în procesul de receptare.

In acest scop, este necesar a se apropia, cât mai intim posibil, lumea interioară a lectorului de lumea textului. Numai prin transpunerea cititorului pe aceeaşi dimensiune afectivă ca şi cea a eului poetic poate fi posibilă o contribuţie substanțială a receptorului la decodificarea şi înţelegerea profundă şi creativă a textului liric. Rolul activităţilor etapei de prelectură este de a sensibiliza cititorul atât față de formele artistice, cât și față de conținutul ideatic.

La proiectarea activităților de prelectură trebuie luate în considerație, așadar, două aspecte esențiale: specificul comunicării artistice în general și, în special, particularitățile estetice ale operei ce urmează a fi studiată. Abordată din perspectiva schemei comunicării, remarcă A. Pamfil, ,lectura apare ca o formă de comunicare atipică, definită prin asimetrie (emiţătorul și receptorul nu sunt coprezenți), non-reversibilitate (rolurile nu sunt interșanjabile, iar feedbackul nu este posibil) și decontextualizare (receptorul nu are acces la contextul enunțării, tot așa cum emițătorului îi este străin contextul receptării) " [8, p. 132]. Aceste aspecte trebuie luate în calcul, la fel ca și faptul că opera literară nu este un produs finit, stabil, închis; nu este doar opera autorului, ci şi opera cititorului, în aceeaşi măsură. De aceea, se recomandă profesorilor de limbă şi literatură română să ofere elevilor mai multă libertate de interpretare a textelor poetice, să accepte viziunile originale (fondate logic) ale elevilor, asociate experienței personale, şi nu doar pe cele care consună cu posibilităţile hermeneutice relevate în reperele metatextuale.

Pregătirea elevului la nivel afectiv se poate efectua prin strategii didactice care vor avea asupra elevului un impact similar celui 
al comunicării poetice: de a produce emoţii. Or, „textul liric transmite stări sufletești și sentimente, mai puțin idei; elevul trebuie să simtă înainte să înţeleagă. Când se ajunge la o empatie cu textul, se poate vorbi și de o înțelegere a mesajului, care nu este decât o transpunere în cuvinte a stărilor și sentimentelor transmise" [3, p. 30]. Crearea unei stări afective pre-lectorale și conștientizarea acesteia de către elevi va asigura un contact mai apropiat al cititorului cu textul chiar din prima lectură. Textul necunoscut va deveni, astfel, un text aşteptat, elevului stimulându-i-se şi gustul pentru arta literară. Printre strategiile didactice, pentru etapa de prelectură, ce pot determina cititorul să ofere un răspuns afectiv adecvat în receptarea poeziei se pot enumera: Freewritigul, Câmpul asociativ/Asocierile libere, Asocierile forțate, Graffitiul, Blițul, pornind de la un cuvânt/temă/motiv/simbol/citat/melodie/ima gine etc. (elementele acumulate pot fi organizate, eventual, în formă de Clustering, reţele, trepte, grupuri sau serii logice). Exerciţiile scrise sau orale prelectorale trebuie să anticipeze, într-o oarecare măsură, reprezentările și imaginile artistice care vor fi create de textul liric.

În cazul în care textul se centrează mai mult pe idei (ne amintim de poezia de idei a lui L. Blaga), cu o puternică rezonanţă în realitatea exterioară, contemporană, poate fi oportună evocarea unor experienţe similare ale elevilor, înainte de a trece la lectura poeziei. Acest proces poate fi realizat prin chestionare orală frontală, discuţie ghidată sau oricare altă formă de dialog profesor-elevi și prin tehnici ca Pagina de jurnal, Brainwritingul sau Linia valorii, Pixuri în pahar, Găsește pe cineva care... ș.a. Pentru a stimula potenţialul creativ şi interpretativ al elevului, se poate folosi procedeul anticipării conţinutul ideatic al textului printr-un cuvânt-cheie, prin cuvântul-temă, un motiv literar (laitmotivul textului), titlu, o pereche de cuvinte contrastante etc., prin care se poate prevedea/presimţi spectrul afectiv al textului. În acest caz, ar fi utile tehnicile Presupunerea prin termeni $[11$, p. 18] sau Revizuirea termenilor-cheie [6, p. 10], condiţia fiind ca după lectura inițială a textului să se revină la rezultatele acestei activități, verificând gradul de satisfacere a așteptărilor receptorilor. De asemenea, anticiparea conținutului se poate realiza printr-un pre-text $\mathrm{cu}$ același mesaj emoțional/etic: comentarea unui citat (o modalitate supralicitată în practica instructiv-educativă) sau a unui fragment din alt text, selectat prin criteriul asemănării de idei. Calitatea comprehensiunii textului liric ar putea fi asigurată și prin abordarea concentrică, pornind de la analiza şi interpretarea elementelor paratextuale 
(aspectul grafic, forma, nuanțele cromatice, elementele evidențiate, imaginile, mottoul, dedicația volumului/plachetei) înainte de a trece la lectura textului.

Pregătirea elevilor la nivel cognitiv vizează şi reactualizarea datelor despre viaţa şi activitatea literară a autorului, care va îmbogăți orizontul cultural al elevilor și va facilita o posibilă abordare biografică a textului. Textul liric este cel în care eul poetic este perceput ca voce a autorului, de aceea, interpretarea biografică/psihologică poate fi revelatorie. Dimensiunile personalității socioculturale a autorului, dar și individualitatea sa creatoare se descoperă prin strategii care constau în prelucrarea intelectuală a unor informații biobibliografice sau critice (metaliterare) brute: Interviul în trei trepte, Mozaic, SINELG, Gândește-Perechi-Prezintă, ȘtiuVreau să știu-Învăț, CV-ul scriitorului, Scheletul de pește, Axa biografică și prin alte modalități de transpunere rezumativă a datelor într-o anumită formă grafică sau care se axează doar pe selectarea informațiilor relevante şi prezentarea lor publică: referat, discurs oral cu sau fără suport audiovizual. Este eficientă și vizionarea unor filme documentare, secvențe video, emisiuni TV, interviuri televizate etc. și rezumarea ori completarea unor chestionare pe baza lor sau, invers, alcătuirea de către elevi (după ce a fost vizionat materialul) a unei liste de întrebări suplimentare despre autor, la care vor răspunde colegii sau profesorul.

Pentru etapa de prelectură este, de asemenea, oportun a se realiza activităţi de stimulare a gândirii critice şi a se face o revizie a instrumentarului de analiză lingvistică şi literară a textului poetic (noțiunile literare: specie/gen liric, figuri de stil, imagini artistice, motiv/leitmotiv, elemente prozodice etc. și/sau noțiunile de fonetică, morfologie, lexicologie, sintaxă și punctuație). Acest moment ar oferi posibilitatea de a se face cunoştinţă cu textul printr-o modalitate netradiţională, diferită de lectura propriu-zisă, fără a o exclude. În funcţie de specificul şi dimensiunile textului literar, profesorul va decide dacă este necesară această activitate de trecere de la prelectură la lectură şi analiză. Activităţile propuse mai jos pregătesc perceperea funcţionalităţii gramaticale şi lexicosemantice a secvenţelor textuale (rezultate ale combinatoricii originale stabilite de către autor) prin operaţii asupra limbajului poeziei.

Conexiuni. Profesorul scrie pe tablă cuvintele semnificative ale textului, la forma iniţială sau aşa cum apar în text, şi elevii ies pe rând la tablă şi stabilesc legături/asocieri posibile între ele, unindu-le cu linii şi motivând conexiunile. Elevii (individual sau în perechi) vor modifica formele gramaticale ale cuvintelor şi vor forma îmbinări, iar după 
prima lectură a textului liric, se va verifica câte dintre îmbinările fixate se găsesc în text. De asemenea, se poate face 0 comparaţie între modul autorului şi cel al elevilor de a combina cuvintele.

Experimentul literar. Textul liric necunoscut apare înaintea elevilor (pregătit din timp pe fişe, scris sau proiectat pe tablă), având spaţii libere în locul unor cuvinte semnificative (substantive, verbe, adjective). Elevii intuiesc posibile modalităţi logice de includere a cuvintelor necesare în context, le plasează, potrivindu-le gramatical, semantic, expresiv şi prozodic, apoi prezintă varianta proprie a poeziei. După prima lectură a poeziei care se va studia, se pot compara anumite secvenţe ale textului autorului cu secvenţe din variantele propuse de elevi.

Anticipări creative. Se aleg trei cuvinte-cheie din poezie şi elevii alcătuiesc cu acestea câte o figură de stil/imagine artistică (auditivă, vizuală, olfactivă, tactilă, la alegerea profesorului sau la propria discreţie). Se vor compara modul în care cuvintele au fost utilizate de elevi şi semnificaţia pe care le-a dat-o autorul. Plăcerea descoperirii conştiente a unei poezii, la lecţie, poate fi produsă şi printr-o conversație euristică, punând accent pe cazurile când anticipările emise la etapa de prelectură se confirmă prin elementele textului.
Un impact benefic asupra formării elevilor poate avea și valorificarea, la etapa de prelectură, a aspectului transdisciplinar al limbii și literaturii române. Interesul elevului faţă de textul ce urmează a fi studiat poate fi provocat printr-o operă similară (sub aspectul temei, motivelor, imaginilor artistice etc.) dintr-o altă artă (pictură, sculptură, muzică, coregrafie, teatru, arhitectură ș.a.) sau, dacă este posibil şi plauzibil (la studiul poeziei moderniste, de exemplu), prin prezentarea unor produse sau procese din anumite ştiinţe.

\section{Modalități de lectură a textului}

liric. Predarea textului liric reprezintă un proces complex, reușita căruia depinde de corectitudinea organizării didactice a mai multor etape: prelectura, lectura și postlectura. De obicei, cadrele didactice acordă mai mult spațiu, în proiectul de lecție, și consistență metodică primei și ultimei faze, punând accent pe activități care anticipează stratul de idei al poeziei sau care dezvoltă diferite competențe ale elevilor, pornind de la conținutul acesteia. Etapa de lectură este însă esenţială în didactica textului liric, nu numai pentru că premerge în mod strategic postlecturii (analizei și interpretării), ci şi fiindcă determină în mod direct calitatea acesteia.

Există mai multe tipuri de lectură care pot fi practicate la lecțiile de limbă și literatură română. Prima și cea mai simplă 
tipologizare include lectura informativă (lectura tehnică, înțelegerea literală a textului) și lectura literară (lectura textului ca produs cultural, ca formă a artei). Lectura literară poate fi categorisită, conform etapelor procesului de receptare a textului artistic, în:

1. lectura inițială/cognitivă (decodificarea și înțelegerea stratului lexico-semantic al textului);

2. lectura analitică, sau explicativă (lectura dirijată, impresiile de lectură);

3. lectura interpretativă (conferirea de semnificații textului);

4. lectura critică (aprecierea textului).

Lectura inițială poate fi realizată prin mai multe modalități, în funcție de obiectivele preconizate. Elevul poate citi poezia în gând, în şoaptă, cu voce tare sau alternativ (o secvență cu voce, alta - în gând). Poezia poate fi lecturată individual, în perechi (pe rând, ascultându-se reciproc); unele texte lirice permit chiar și lectura pe roluri (cum e, de pildă, poezia „Formular” de G. Vieru). Lectura poeziei poate fi executată integral, selectiv (la solicitarea profesorului), fragmentat: în lanţ (fiecare elev citește câte o secvență, în ordinea în care stau aranjați în bănci) sau în ştafetă (un elev lecturează un fragment și numește cine va citi următoarea secvență).
La predarea textului liric, trebuie să se facă o deosebire tranșantă între lectura de informare și lectura de plăcere. „Abordarea afectivă/emoţională” $[7$, p. 56] a textului este esenţială pentru înţelegerea mesajului global. De aceea, se recomandă ca elevilor să li se ofere un model de lectură expresivă a textului poetic. Lectura-model poate fi executată de către cadrul didactic sau de un alt profesionist (înregistrare audio sau video a textului în lectura autorului sau a altui interpret), deoarece greşelile ortoepice şi cele de intonaţie, de accent logic sau de pauze logice (chiar şi cele aparent inofensive), în lectura iniţială, pot afecta procesul de receptare a poeziei. Modelul de lectură a poeziei lirice pe care îl oferă profesorul asigură contactul elevilor cu textul şi le provoacă o reacţie emoţională, atitudinală, cognitivă adecvată faţă de conţinut şi formă. La etapa de lectură iniţială, profesorul trebuie să capteze şi să demonstreze elevilor momentele incitante, savuroase şi intrigante ale textului, mai ales când este vorba de un text metaforizat, complex, ermetic, din care elevii înţeleg foarte puţin sau nimic, astfel încât, după prima lectură, ei să nu considere poezia ce li s-a propus o ,uşă încuiată”, ci un mister fascinant, care se vrea dezvăluit.

Desigur că imitarea modelului de lectură expresivă nu este obligatorie; în limitele posibilităţilor textului, elevul îşi 
poate permite o lectură personalizată, dar rămâne absolut necesar să se respecte modulaţiile intonaţionale pe care le dictează punctuaţia (sau lipsa acesteia) şi accentele logice. Efectuarea corectă din punctul de vedere al articulării şi accentuării a lecturii iniţiale este extrem de importantă, când elevilor li se va cere să memorizeze şi să recite poezia. Prin recitare, de altfel, elevii trebuie să subînţeleagă o modalitate de dezvoltare a abilităţilor retorice, nu un exerciţiu banal, de rutină. Totodată, o singură lectură a textului este insuficientă pentru a trece imediat la analiză, de aceea, după lectura iniţială, se poate continua prin alte modalităţi de lecturare a textului. Lectura individuală reprezintă o modalitate de apropriere a cititorului de text, deoarece el îşi creează, cu propria voce, o posibilitate nu numai de enunţare, ci şi de interiorizare, de receptare a textului în concordanţă cu propriul mod de a fí şi de a înţelege lumea. Lectura individuală a textului liric trebuie să fie o lectură conştientă, în care cititorul este implicat intelectual şi emoţional, înţelege şi empatizează cu eul liric, sesizând ideile şi mesajul pe care le transmite. Totodată, el trebuie să înţeleagă şi să accepte convenţiile de gen/specie/curent. Un cititor format se va delecta cu ceea ce înţelege şi apreciază drept artistic, inedit, original într-un text şi va fi tentat să descopere ceea ce este neînţeles sau necunoscut.
De asemenea, se poate organiza o lectură combinată (pe fondul unei melodii, însoțită de prezentarea unor imagini). Profesorul poate solicita elevilor să selecteze o melodie instrumentală tematică (muzică melancolică, veselă, relaxantă, meditativă, solemnă, gravă ş.a.), iar la lectura poeziei, dintre melodiile acumulate să fie propuse pentru audiere cele ce se potrivesc atmosferei lirice; se poate practica lectura pe fond muzical a poeziei. De asemenea, elevii pot crea ei înșiși o colecţie de imagini pe o temă (noaptea de vară, iarna, răsăritul soarelui, luna, curcubeul, ninsoarea, etc.), prezentându-le (în Power Point, Movie Maker, Prezi sau în oricare alt program) pe cele care se asociază cu textul ce se lecturează. Colecţiile de imagini sau melodii ale elevilor pot fi descrise, iar corespondenţele/asocierile $\mathrm{cu}$ textul se pot discuta, argumenta. Selecţia melodiei sau a colajului de imagini poate fi făcută şi de către profesor, în prealabil, pentru a îmbogăţi lectura poeziei la lecţie.

Ca formă a artei, poezia trebuie să înveţe elevul să fie sensibil nu numai faţă de arta literară, ci şi faţă de elementele estetice ale realităţii imediate, faţă de manifestările naturii şi existenţei în general, pe care trebuie să le savureze, să le trăiască. De aceea, pe parcursul treptelor şcolare, este firesc ca, la lecţiile de limbă şi literatură română, lectura tehnică (cognitivă) să 
evolueze într-o lectură expresivă. Pentru realizarea unei lecturi expresive, se vor lua în considerație aspecte ce țin de:

- intonație: interogativă, exclamativă, enunţiativă, imperativă;

- melodia versului/frazei: ascendentă, descendentă, rectilinie, săltăreață, monotonă etc.;

- tonul fundamental: narativ, meditativ, filosofic, solemn-patetic, convențional;

- accentele logice;

- pauzele de durată: de scurtă durată (marcate de virgulă sau de cezura din interiorul versului), duble (scoase în evidență de semnele exclamării, interogării ori de punctul de la sfârșitul enunțului); triple (necesar a fi respectate la sfârşitul textului ori în cazul punctelor de suspensie);

- pauzele psihologice: de reflecție, de tensiune, de reamintire etc. [10, pp. 5859].

Elevul trebuie obişnuit să citească o poezie primind satisfacţia pe care o simte de la contactul cu oricare altă formă de artă (muzică, pictură, sculptură, dans ş.a.). De asemenea, lectura expresivă poate evolua, prin memorare și recitare, într-o lectură artistică/teatralizată, realizată de elevi pe post de actori, costumați adecvat, în cadrul unui decor special (cu joc de lumini, sonorizare etc.).
$\mathrm{Nu}$ în ultimul rând, lectura unui text liric trebuie să înveţe tânărul cititor să privească în sine, să-şi autoanalizeze sfera emoţională şi să se înţeleagă. Poezia provoacă „furtuni” de asocieri între cuvinte, realităţi şi sentimente, lectura îl poate face atent pe elev la cauzele şi efectele unui sentiment, la impactul unui stimul asupra propriului său spectru emoţional. Atât lectura, cât şi interpretarea unui text liric va duce la dezvoltarea inteligenţei emoţionale a cititorului sau, cel puţin, îl va face să cunoască noi experienţe emoţionale.

Strategii postlectorale. Etapa de postlectură poate începe cu activități care urmăresc exteriorizarea primelor reacții afective, reflexive, asociative ale elevilor la textul propus spre studiere. După audierea lecturii-model (în interpretarea profesorului, a unui actor, a autorului - materiale audio, video ș.a.) și/sau după lectura individuală a poeziei, se pot aplica metode de înregistrare a reacţiei imediate, aplicându-se tehnici de tipul Reacţia cititorului, Agenda cu notiţe paralele, tehnica VAS, se pot prezenta și comenta, prin discuție ghidată, secvențele cele mai emoționante din text. Aceste activități vor avea drept rezultat conştientizarea de către tânărul cititor a propriilor reacţii față de poezie în calitate de produs estetic și raportarea sa atitudinală la semnificaţiile de suprafaţă. Fixarea primelor impresii este necesară și pentru compararea 
acestora cu interpretările și aprecierile finale, globale, dezvoltându-se atât capacitatea de intuire a mesajului (prin titlu, cuvinte-cheie, motive, atmosferă afectivă), cât şi abilitatea de lucru cu textul într-un proces sistematizat, care, adus la automatism, va deveni o competență de lectură independentă a poeziei dincolo de pereții şcolii.

Totodată, în etapa de postlectură, procesul de receptare va continua în câteva faze principale: 1. analiza textului liric; 2. interpretarea și 3. evaluarea/integrarea. Cea mai migăloasă dintre ele pare a fi analiza. Conform dicţionarului explicativ, termenul a analiza are sensurile principale de „1. A cerceta un întreg, un fenomen etc., examinând fiecare element în parte. 2. A examina un text din diferite puncte de vedere" [12, sub voce a analiza]. Procesul de analiză, prin urmare, presupune câteva operaţii intelectuale: „descompunerea” întregului în componente; examinarea separată a fiecărei părţi; descrierea părţilor din diferite perspective; identificarea funcţiei fiecărei părţi în cadrul întregului şi a interdependenţei dintre părţi. În urma realizării calitative a acestor operații, se poate trece la sinteză, care constă în reasamblarea întregului perceput prin prisma părţilor constituente, adică la un nivel profund şi complex - de interpretare şi evaluare.
Analiza poeziei presupune o relectură a acesteia, însă concentrată nu pe procesul lecturii în sine, ci pe identificarea şi observarea unităţilor, trăsăturilor şi principiilor funcţionale ale elementelor, în vederea reconstituirii substanţei de idei. Realizând trecerea de la perceperea prin lectură a „corpului” poetic ca întreg la cercetarea detaliilor, analiza face posibilă înţelegerea profundă a textului la mai multe niveluri. Prin analiză, fiecare element trebuie să devină, explicit, atât parte componentă, cât şi să fie raportat la alte constituente şi la întreg. Eficienţa procesului analitic va spori atunci când, înainte de a purcede la activităţile analitice, se vor lua în calcul particularitățile textului (aspectele de conţinut şi de formă: specia, particularităţile compoziţionale şi prozodice, substraturile semnificante) şi se va trece în revistă instrumentarul necesar, în raport cu cel posedat de tinerii cititori (în caz că acest lucru nu s-a făcut în etapa de prelectură). Dacă diferenţa dintre „setul” de noţiuni necesare unei analize optime şi cel pe care elevii îl posedă la moment este prea mare, atunci textul va fi inaccesibil pentru această categorie de cititori, iar rezultatele analizei şi interpretării vor fi superficiale.

Analiza va începe, așadar, cu procedura de descompunere structurală a textului în unităţi. Această activitate va face cititorul să descopere multitudinea şi 
diversitatea elementelor ce formează mecanismul textual, procesul de fragmentare realizându-se aparte sau în complementaritate cu observarea, cercetarea particularităţilor detaliilor identificate, definirea lor. Pentru o abordare analitică logică, acest proces se poate efectua pe niveluri:

- fragmentarea compoziţională: numărul de strofe, numărul de versuri în strofă; măsura versurilor;

- fragmentarea lexico-semantică: observarea și înțelegerea tehnică a faptelor de limbă;

- fragmentarea fonetică: identificarea elementelor care produc efecte sonore evidente (prozodice, stilistice);

- fragmentarea limbajului artistic în unităţi: identificarea figurilor de stil;

- fragmentarea lumii reprezentate: identificarea instanţelor artistice (eul poetic, personajele lirice, adresantul), imaginilor artistice etc.

Structural, o operă lirică poate fi fragmentată conform varii criterii. „Alte opere lirice, ca, de exemplu, pastelurile, pot fi construite din unu, două sau mai multe tablouri, a căror delimitare se poate realiza în funcţie de posibilitatea de a raporta fiecare tablou la imaginea integrală a poeziei” [3, p. 16]. O modalitate didactică tradiţională de fragmentare, observare şi definire a unităţilor unui text artistic se efectuează prin lectura explicativă. Incluzând un „complex de metode, ea reprezintă o adevărată strategie didactică, deoarece lectura explicativă necesită conversaţie, explicaţie, povestire şi chiar demonstraţie" [Ibidem]. L. Antonesei încearcă o delimitare în etape a acestei strategii. „Etapele, sau stadiile lecturii explicative, prin care se face receptarea mesajului textului (îndeosebi la acela narativ) sunt următoarele:

- citirea integrală a textului;

- lecturarea pe fragmente şi analiza la prima vedere a acestora se poate realiza în mod tradiţional, prin discuţia ghidată sau interogarea frontală: cum înţelegeţi expresia sau secvenţa...?

- conversaţia generalizatoare, $\mathrm{cu}$ privire la conţinutul textului;

- recitirea de încheiere, care ar putea certifica-consolida opiniile lansate" [1].

Prin lectura explicativă se verifică gradul de înţelegere a semnificaţiilor semantice ale cuvintelor. „Se consultă dicţionarul pentru elucidarea semnificaţiilor cuvintelor noi şi selectarea sensului celui mai potrivit al cuvântului în contextul din care a fost luat, se atribuie semnificaţii provizorii (care vor fi certificate sau infirmate la şi după etapa de analiză) unor expresii inedite [Ibidem]. Eventual, noile 
achiziţii lexicale pot fi valorificate în alte produse ale unor sarcini în acest scop, numărul şi cerinţele cărora nu vor cauza abateri de la temă sau suspendări îndelungate ale procesului de receptare a textului artistic. Un efect benefic pot avea sarcinile care se încheie cu o comparaţie a paradigmaticii unor unităţi lexicale în poezie şi în limbajul curent.

$\mathrm{Cu}$ lectura explicativă începe, de fapt, într-un mod mai delicat, analiza lingvistică, rezonabil a fi efectuată înainte de a trece la analiza literară, deoarece elementele acesteia constituie unităţi mai mici, care, formând unităţi complexe, creează structuri semnificante (ale lumii imaginate) în textul liric. Prin analiza lingvistică a poeziei, pe lângă faptul că se pun în aplicare noțiunile gramaticale studiate, obținem date importante pentru analiza literară și se facilitează procesul de interpretare și evaluare a textului studiat. Iată aspectele de limbă care pot prezenta interes într-o poezie:

\begin{tabular}{|c|c|c|c|c|c|}
\hline \begin{tabular}{|l|} 
Analiza \\
fonetică
\end{tabular} & Analiza lexicală & $\begin{array}{l}\text { Analiza } \\
\text { morfologică }\end{array}$ & \begin{tabular}{|l|} 
Analiza \\
sintactică
\end{tabular} & \begin{tabular}{|l|} 
Analiza \\
ortografică
\end{tabular} & \begin{tabular}{|l|} 
Analiza \\
punctuaționa \\
lă
\end{tabular} \\
\hline \begin{tabular}{|l} 
Vocale/co \\
nsoane; \\
diftongi, \\
triftongi, \\
hiat etc., \\
prezente \\
în poezie
\end{tabular} & $\begin{array}{l}\text { Cuvintele mono- și } \\
\text { polisemantice; } \\
\text { sinonime, } \\
\text { antonime, } \\
\text { omonime, } \\
\text { paronime; } \\
\text { arhaisme, } \\
\text { neologisme; } \\
\text { forme populare; } \\
\text { regionalisme; } \\
\text { cuvinte diminutive/ } \\
\text { augmentative; } \\
\text { forme rare; } \\
\text { expresii } \\
\text { frazeologice; } \\
\text { creații lexicale etc. }\end{array}$ & $\begin{array}{l}\text { Părtile de } \\
\text { vorbire } \\
\text { (substantive, } \\
\text { adjective, } \\
\text { verbe, } \\
\text { adverbe, } \\
\text { pronume, } \\
\text { prepozitiii, } \\
\text { conjuncții, } \\
\text { articole) }\end{array}$ & \begin{tabular}{|l|} 
Părțile de \\
propoziție; \\
structura \\
unitătilior \\
sintactice \\
ale \\
versurilor \\
(propoziții \\
și fraze)
\end{tabular} & $\begin{array}{l}\text { Ortografierea } \\
\text { diferitor părți } \\
\text { de vorbire } \\
\text { din textul } \\
\text { liric studiat }\end{array}$ & $\begin{array}{l}\text { Folosirea } \\
\text { anumitor } \\
\text { semne de } \\
\text { punctuație in } \\
\text { poezie - } \\
\text { particularitățil } \\
\text { e și rolul } \\
\text { acestora }\end{array}$ \\
\hline
\end{tabular}

Pe lângă diversitatea de exerciții gramaticale pe care o propun manualele, culegerile de teste și alte resurse didactice, se mai pot practica, în acest sens, diverse jocuri, cum ar fi Segmentarea fonemică fulger (pe masă sunt aşezate carduri cu câte un cuvânt, cu faţa în jos, fiecare elev primeşte sarcina să aleagă cuvintele care conţin o anumită literă, diftong, rădăcină, sufix etc.) sau Banca de cuvinte (sunt selectate exemple de cuvinte care se scriu şi se pronunţă la fel, au aceleaşi ortograme, grupuri de litere care se pronunţă şi se scriu greu etc.; se lucrează asupra structurii cuvântului: câte sunete, câte litere, cum le pronunţăm, câte silabe etc.) [2, p. 8].

\begin{tabular}{|c|c|c|c|c|}
\hline $\begin{array}{l}\text { Stratul } \\
\text { fonetic }\end{array}$ & $\begin{array}{l}\text { Stratul } \\
\text { lexico- } \\
\text { semantic }\end{array}$ & $\begin{array}{c}\text { Stratul } \\
\text { morfologic }\end{array}$ & $\begin{array}{c}\text { Stratul } \\
\text { sintactic/punctuațional }\end{array}$ & $\begin{array}{l}\text { Stratul } \\
\text { imagistic }\end{array}$ \\
\hline $\begin{array}{l}\text { Tipuri de } \\
\text { rimă, ritm; } \\
\text { organizarea } \\
\text { versurilor în } \\
\text { strofe; } \\
\text { prezența } \\
\text { figurilor } \\
\text { sonore: } \\
\text { aliterație, } \\
\text { asonanță, } \\
\text { eufonie, } \\
\text { onomatopee; } \\
\text { refren, } \\
\text { repetiție, } \\
\text { anaforă, } \\
\text { epiforă, } \\
\text { enumerație; } \\
\text { contraste } \\
\text { sonore }\end{array}$ & 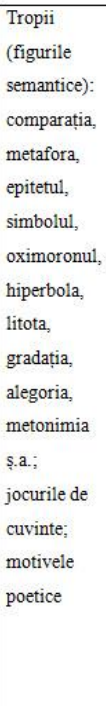 & 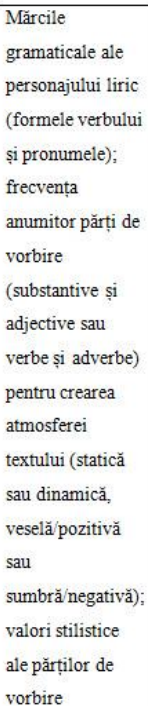 & $\begin{array}{l}\text { Figurile sintactice: } \\
\text { paralelismul; } \\
\text { inversiunea; chiasmul; } \\
\text { valori stilistice ale } \\
\text { elementelor ce țin de } \\
\text { topică; } \\
\text { figurile retorice: } \\
\text { exclamația, invocația, } \\
\text { interogația retorică }\end{array}$ & $\begin{array}{l}\text { Imaginile } \\
\text { artistice, } \\
\text { elemente de } \\
\text { cronotop }\end{array}$ \\
\hline
\end{tabular}
impact dublu asupra elevilor: pe de o parte, le vor consolida cunoştinţele despre noţiunile de limbă şi competenţele de operare cu acestea în activități practice, iar pe de altă parte, îi va obişnui să utilizeze 
resursele lingvistice cu scopul de a descoperi semnificaţiile profunde ale textului artistic.

După analiza lingvistică a poeziei, se va trece la analiza literară, iar elementele elucidate anterior se vor valorifica în concluzii și se vor relaționa cu aceasta din urmă. Analiza literară a textului liric presupune cercetarea specificului limbajului artistic individualizat, inedit, care marchează stilul poetului. În școală, aceasta se realizează în funcţie de instrumentarul teoretic pe care îl posedă elevii de la fiecare clasă. Procesul de analiză literară va începe la lecţie, individual sau colectiv, sub monitorizarea şi ghidarea profesorului, poate continua acasă, iar la revenire, rezultatele acestuia vor fi expuse şi valorificate în etapa de interpretare. Sunt analizate mijloacele de expresie, procedeele stilistice şi prozodice care duc la decodificarea fondului de idei şi sentimente ce au declanşat actul creaţiei, contribuind nemijlocit la reflectarea mesajului poetic. Pentru o predare organizată, se poate aplica o analiză pe straturi a elementelor literare:

Printre jocurile didactice prin care se poate realiza o analiză literară a textului se enumeră și Epitete în lanţ, un joc de tip concurs, în care clasa este divizată în echipe, pentru care e pregătită o bandă din coli. Se pornește de la un cuvânt-temă, care este anunțat la început, benzile trec de la un elev la altul în cadrul fiecărei echipe și elevii scriu câte un epitet (original, la care ceilalți nu s-ar fi gândit), după care îndoaie banda, ca următorii să nu vadă ce a fost deja scris, apoi profesorul citeşte toate epitetele, le numără și le exclude pe cele care se repetă. Câştigă echipa care are cele mai multe sau cele mai originale epitete. Alte jocuri creative pe baza elementelor limbajului artistic ar fi Invazia rimelor: lectură prin analogie (elevii trebuie să alcătuiască liste proprii de cuvinte care rimează şi să nu comită erori la lectura lor [2, p. 9]); Hiperbolizarea (constă în supradimensionarea sau micşorarea obiectului cercetat, a caracteristicilor sale sau doar a unor componente [Ibidem]; astfel, se pot redimensiona elementele care apar în text). Aceste activități presupun abordarea atentă a unităţilor expresive, dar și fixarea noțiunilor literare.

Analiza se va încheia cu sinteză, realizată prin simple concluzii sau prin interpretarea textului liric, care reprezintă conferirea de semnificaţii elementelor constituente, funcțiilor/rolurilor și raporturilor acestora în conturarea imaginilor artistice. Această operație intelectuală este mai complicată, deoarece solicită nu doar gândire critică, experiență lectorală, ci și creativitate, viziune individuală clară asupra lucrurilor puse în discuție. Interpretarea se poate realiza prin tehnici ca GPP, Floarea de lotus 
(formularea ideilor principale/secundare), 6 de ce?, Eseul de 5 minute, Jurnalul reflexiv și activități cum ar fi identificarea/relevarea semnificaţiei unei secvenţe poetice (figură de stil, pereche de versuri, strofã), comentariul literar al unui fragment sau al întregului text (prin care se fructifică produsele procesului de înţelegere într-un text metaliterar personalizat), formularea și comentarea mesajului global, eseul de sinteză. Aceste tipuri de activități se pot realiza și prin organizarea grafică a rezultatelor interpretării sau se pot solda cu produse care îmbină analiza cu interpretarea, așa cum sunt cele propuse în modelele de mai jos:

Modelul 1:

\begin{tabular}{|l|l|l|}
\hline Secvența & $\begin{array}{l}\text { Figura } \\
\text { de stil }\end{array}$ & Semnificaţii/sugestii \\
\hline & & \\
& & \\
\hline
\end{tabular}

Modelul 2:

\begin{tabular}{|l|l|l|}
\hline Versul/versurile & $\begin{array}{l}\text { Asocierile } \\
\text { pe care le } \\
\text { provoacă }\end{array}$ & \\
\hline & & \\
& & \\
\hline
\end{tabular}

Modelul 3:

\begin{tabular}{|l|l|l|}
\hline Fragmentul & $\begin{array}{l}\text { Imagini } \\
\text { artistice }\end{array}$ & Comentarii \\
\hline & & \\
& & \\
\hline
\end{tabular}

O activitate interactivă de lucru în perechi, la interpretarea textului, este tehnica Jurnalul triplu, prin care elevii selectează în tabel câteva (la discreția profesorului) secvențe de text, în prima coloană se introduc comentarii pentru fiecare secvență, apoi elevii schimbă caietul/fișa cu cel/cea a colegului de bancă și se introduc astfel comentarii în coloana a treia, cu privire la fiecare fragment, dar și la modul în care au fost comentate acestea în coloana a doua.

\begin{tabular}{|c|c|c|}
\hline Citate & $\begin{array}{c}\text { Comentariul } \\
\text { propriu }\end{array}$ & $\begin{array}{c}\text { Comentariul } \\
\text { colegului }\end{array}$ \\
\hline & & \\
\hline
\end{tabular}

Procesul hermeneutic trebuie să conducă de la înţelegerea decontextualizată (poezia percepută doar prin elementele lexico-semantice) spre o comprehensiune contextuală (implicând şi biografia autorului, backgroundul literar, istoric, social în care a apărut textul, elementele intertextuale, paratextuale etc.). În clasele liceale, procesul de interpretare va include și o abordare contextuală (raportarea textului la opera integrală a autorului, la specie/gen/curent literar sau chiar la aspecte istorice și sociologice ale epocii): biografică, metafizică, simbolică, arhetipală, mitocritică, axiologică etc. De asemenea, în liceu se vor practica activităţi de metacogniţie, de înţelegere şi conştientizare a modului în care a fost tratat/perceput textul, de meditaţie asupra procesului 
intelectual de creație a unui atare tip de text. La această etapă, elevii vor sesiza elementele care i-au făcut confuzi la început şi modalitățile prin care obstacolele în receptare au fost depășite, iar elementele neclare ale textului au fost elucidate.

Pentru etapa de evaluare/integrare se vor practica activități de prezentare și argumentare a părerii proprii, cum ar fi metoda PRES, care, în opinia specialiștilor, ajută elevii să-şi exprime opinia cu privire la problema abordată în operă, le dezvoltă capacitatea de argumentare. Procedura de aplicare prevede respectarea a patru paşi, aceştia fiind scrişi din timp pe un poster (P.

- Exprimaţi-vă punctul de vedere; R. Faceţi un raţionament (judecată) referitor la punctul de vedere expus; E. - Daţi un exemplu pentru clarificarea punctului de vedere; S. - Faceţi un rezumat (sumar) al punctului vostru de vedere [9]. De asemenea, tehnici eficiente de generalizare, interpretare și expunere/argumentare a ideilor proprii sunt Cercetarea împărtăşităă, Argument în patru paşi, Graficul conceptual, Linia valorii, Păstrează ultimul cuvânt pentru mine, Citate ș.a., scopul concret și etapele cărora sunt descrise în literatura de specialitate [11]. Opiniile și ideile elevilor se vor raporta și la aprecierile critice, care pot fi analizate și discutate frontal, în perechi, în echipe, comentate individual, exprimând argumentat acordul sau dezacordul cu acestea. Având în vedere că ,autorul, ca şi textul, nu determină niciodată un singur semnificat, din contra, generează mai mulţi semnificați, chiar laolaltă şi deodată, relativizând şi destabilizând înțelegerea ca atare a textului” [5], profesorii ar trebui să fie receptivi, deschiși, permisivi în ceea ce privește interpretarea de către elevi a stratului de idei în moduri diverse, neașteptate, chiar contradictorii, în condițiile în care aceștia își argumentează logic și își ilustrează cu exemple opiniile.

În fine, orice text liric nou testează capacitatea elevilor de a cerceta fenomenele lingvistice și literare, dar și de a le înţelege într-un mod general sau particular, inedit. $\mathrm{O}$ receptare eficientă a poeziei va duce la interiorizarea ideilor şi experienţelor intime, la topirea fondului de idei al textului în structura spirituală a elevului, condiționând favorabil modul său de viață.

\section{Bibliografie}

1. ANTONESEI, L. O introducere în pedagogie. Iaşi: Polirom, 2002.

2. CARTALEANU, T., GORAŞPOSTICĂ, V., HANDRABURA, L. Depăşirea dificultăţilor la lectură şi scriere. Chişinău: Centrul Educaţional Pro Didactica, 2007.

3. CIOBANU, F. Elemente de metodică a predării limbii şi literaturii române.

Budapest: ELTE, 2015 [citat 
20.09.2019]. Disponibil:

https://metodika.btk.elte.hu/file/TAMO

P BTK_BMK_5.pdf

4. COSTEA, O. Didactica lecturii - o abordare funcțională. Iaşi: Institutul European, 2006.

5. Curriculum național la limba și literatura română, clasele V-IX. Chișinău, 2019.

6. Limba și literatura română, ghid de implementare a curriculumului modernizat în învățământul liceal. Chișinău: Știința, 2007.

7. NOREL, M., SÂMIHĂIAN,

F. Didactica limbii şi literaturii române, II, Proiectul pentru învăţământul rural. MEC, 2006.

8. PAMFIL, A. Limba şi literatura română în gimnaziu. Structuri didactice deschise. București: Paralela 45, 2003 [citat 14.11.2019]. Disponibil: http://www.scritub.com/profesorscoala/Formarea-competentei-decompre151314225.php

9. ȘCHIOPU, C. Interpretarea textului literar: tehnici de creativitate. În: Limba română, 2011, nr. 11-12 [citat 17.12.2019]. Disponibil: http://limbaromana.md/index.php?go=a $\underline{\text { rticole\& }}=1306$.

10. ȘCHIOPU, C. Metodica predării literaturii române. Chișinău, 2009.

11. TEMPLE, Ch., Steele, J.L., Meredith, K.S. Aplicarea tehnicilor de dezvoltare a gândirii critice, supliment al revistei Didactica Pro..., ghidul IV, adaptare de: Cartleanu, T., Cosovan, O. Chișinău, 2003.

12. www.dexonline.ro 